\title{
Hepatitis $C$ virus quasispecies evolution during pregnancy and between consecutive pregnancies: influence of maternal immune
} responses

\author{
Myriam Troesch ${ }^{* 1,2}$, Isabelle Meunier ${ }^{1,2}$, Christine Lepage ${ }^{1,2}$, \\ Johanne Samson ${ }^{3}$, Normand Lapointe ${ }^{3,4}$, Marc Boucher ${ }^{3,5}$ and \\ Hugo Soudeyns ${ }^{1,2,4}$
}

\begin{abstract}
Address: ${ }^{1}$ Unité d'immunopathologie virale, CHU Sainte-Justine, Montreal, Quebec, Canada, H3T 1C5, ${ }^{2}$ Department of Microbiology \& Immunology, Université de Montréal, Montreal, Quebec, Canada, H3C 3J7, ${ }^{3}$ Centre maternel et infantile sur le SIDA, CHU Sainte-Justine, Montreal, Quebec, Canada, H3T 1C5, ${ }^{4}$ Department of Pediatrics, Université de Montréal, Montreal, Quebec, Canada, H3C 3J7 and ${ }^{5}$ Department of Gynecology \& Obstetrics, Université de Montréal, Montreal, Quebec, Canada, H3C 3J7

* Corresponding author
\end{abstract}

from Fourth Dominique Dormont International Conference. Host-Pathogen Interactions in Chronic Infections

Paris, France. 13-15 December 2007

Published: 9 April 2008

Retrovirology 2008, 5(SuppI I):OII doi:I0.II86/I742-4690-5-SI-OII

This abstract is available from: http://www.retrovirology.com/content/5/SI/OII

(c) 2008 Troesch et al.; licensee BioMed Central Ltd.

\section{Background}

Hepatitis C virus (HCV) can be transmitted from motherto-child during pregnancy and childbirth. Most importantly, the rate of vertical HCV transmission is increased four-fold in the presence of maternal coinfection with human immunodeficiency virus type 1 (HIV-1). To gain insight into the evolution of HCV disease during pregnancy and to better understand the influence of HIV-1 coinfection, HCV quasispecies composition was characterized longitudinally in a group of 17 pregnant women infected with HCV, including 13 subjects coinfected with HIV-1, 4 of whom were followed during 2 consecutive pregnancies.

\section{Materials and methods}

HCV RNA was extracted from serum and E2 hypervariable region 1 (HVR1) and flanking regions (positions 12781889) were amplified by RT-PCR. Amplicons were cloned and plasmid DNA from transformants was sequenced unidirectionally. Sequences were aligned using Clustal X. A mean of $18.8 \mathrm{cDNA}$ clones of HVR1 were analyzed per time point $(1,337$ clones representing 1,101 non redundant sequences). Mean genetic distance ( $\mathrm{p}$ distance) and its standard deviation were calculated using MEGA2.1. $\mathrm{dN} / \mathrm{dS}$ ratios were computed according to the Nei-Gojo- bori method. Normalized Shannon entropy (Sn) was used to account for the frequency of each different variant in the quasispecies. Diversification of viral variants was assessed using phylogenetic reconstructions built according to the neighbour-joining method and the Kimura twoparameter model.

\section{Results}

Median aspartate aminotransferase and HCV RNA levels were higher in coinfected subjects throughout pregnancy, with 3d trimester HCV RNA levels significantly higher than those observed in subjects infected with HCV alone ( $\mathrm{p}=0.0283$, Mann-Whitney U test). Quasispecies complexity based on numbers of HVR1 variants or Shannon entropy was higher in subjects treated with and responding to antiretroviral therapy (treated-responders; $\mathrm{n}=11$ ) than in untreated-nonresponders $(\mathrm{n}=6)$ or subjects infected with HCV alone $(n=4)$ at all time points examined. Analysis of $\mathrm{dN} / \mathrm{dS}$ ratios revealed that intrahost selective pressure was consistently larger in treatedresponders than in HCV-only subjects, and always higher in HCV-only than in untreated-nonresponders. Finally, the level of diversification of HVR1 observed between consecutive pregnancies was incompatible with linear genetic drift during the inter pregnancy interval. 


\section{Conclusion}

Overall, these results indicate that: a) coinfection with HIV-1 leads to reduced immune pressure on HVR1; b) this immunosuppressive effect is overturned by antiretroviral treatment; and c) pathological events observed in HCVinfected women in late pregnancy are immune-mediated. This study will lead to a better understanding of therapeutic and immune factors that influence viral evolution and the clinical outcome of hepatitis $\mathrm{C}$ during pregnancy.

Publish with Biomed Central and every scientist can read your work free of charge

"BioMed Central will be the most significant development for disseminating the results of biomedical research in our lifetime. " Sir Paul Nurse, Cancer Research UK

Your research papers will be:

- available free of charge to the entire biomedical community

- peer reviewed and published immediately upon acceptance

- cited in PubMed and archived on PubMed Central

- yours - you keep the copyright

Submit your manuscript here:

http://www.biomedcentral.com/info/publishing_adv.asp 